\title{
The racer goby, Babka gymnotrachelus (Kessler, 1857) invades the Evros river: evidence of recent establishment in Greece
}

\author{
Stamatis Zogaris*, Alexandros Ntakis and Roberta Barbieri \\ Hellenic Centre for Marine Research, Institute of Marine Biological Resources and Inland Waters, Athinon-Souniou Ave. Anavissos, \\ Attica 19013, Greece
}

\begin{abstract}
The discovery of the racer goby Babka gymnotrachelus in the transboundary Evros river basin, collected on September 10th 2018 at two locations very close to the Greek-Bulgarian and Greek-Turkish borderlines, is reported. This is a new addition to the non-native ichthyofauna of Greece and the Aegean Sea drainages, and it is the second non-native Ponto-Caspian goby to enter this river. Boat-based electrofishing sampling, following the EU Water Framework Directive monitoring program, provides first evidence of what is presumed to be a recently established population; most of the 13 collected specimens are juveniles and the species has not yet been located in the river's tributaries. Further study and international cooperation in monitoring and management of this and other alien species in the Evros are proposed.
\end{abstract}

Keywords: Babka gymnotrachelus / Evros river / alien species / transboundary river / Balkans

Résumé - Le gobie coureur, Babka gymnotrachelus (Kessler, 1857) envahit la rivière Evros : preuve d'une implantation récente en Grèce. La présence du gobie coureur Babka gymnotrachelus dans le bassin transfrontalier du fleuve Evros, prélevé le 10 septembre 2018 à deux endroits très proches des frontières gréco-bulgare et gréco-turque, est signalée. Il s'agit d'un nouvel ajout à la faune ichtyenne non indigène de la Grèce et aux bassins versants de la mer Égée, et c'est le deuxième gobie Ponto-Caspien non indigène à entrer dans cette rivière. L'échantillonnage de la pêche à l'électricité par bateau, conformément au programme de surveillance de la Directive-cadre sur l'eau de l'UE, fournit les premières preuves de ce qui est présumé être une population récemment établie ; la plupart des 13 spécimens prélevés sont des juvéniles et l'espèce n'a pas encore été trouvée dans les affluents de la rivière. Il est proposé de poursuivre l'étude, et la coopération internationale en matière de surveillance, et de gestion de cette espèce et d'autres espèces exotiques dans la région d'Evros.

Mots clés : Babka gymnotrachelus / rivière Evros / espèce exotique / rivière transfrontalière / Balkans

The racer goby Babka gymnotrachelus (Kessler, 1857) is native to the river catchments of the Black, Marmara and Caspian seas (Miller \& Vasil'eva, 2003). Since the mid 1990s, this goby has invaded several central European rivers although it has not been recorded in Balkan rivers that enter the Mediterranean (Piria et al., 2017a; Koutsikos et al., 2019). Here we report on the recent discovery of $B$. gymnotrachelus in the transboundary Evros-Maritza-Meriç basin (hereafter Evros, the classical name), the largest river in the Balkans after the Danube. The Evros has been called an "open-door" for invading alien species (Ozulug et al., 2018); that is, humanassisted species dispersal which drift downstream of Bulgarian entry points. This dispersal pathway concerns species introduced from Bulgaria's Danubian and Black Sea basin

\footnotetext{
*Corresponding author: Corresponding author: zogaris@hcmr.gr; zogaris@gmail. com
}

freshwater fauna. In recent years another non-native PontoCaspian goby, the Pontian monkey goby Neogobius fluviatilis (Pallas, 1814) was documented in Bulgarian (Stefanov et al., 2008) and Greek parts of the Evros basin (Zogaris and Apostolou, 2011) but despite several sampling visits, the population in Greek waters was not re-located (Economou et al., 2016; Zogaris et al., 2018) and no new non-native gobies were recorded in this river until now.

During September 10th 2018, 13 specimens of $B$. gymnotrachelus were collected on routine EU Water Framework Directive (EU WFD) fish monitoring within Greek territory in the Evros. Electrofishing surveys are undertaken with a five-meter aluminum boat that holds a generatorpowered direct-current electrofisher (EFKO, $8 \mathrm{~kW}, 150-300 /$ $300-600 \mathrm{~V}$ ) with a hand-held netted ring anode of $40 \mathrm{~cm}$ diameter (effective electric field of about $2.5 \mathrm{~m}$ diameter). This method catches fishes along the banks and at depths of down to 


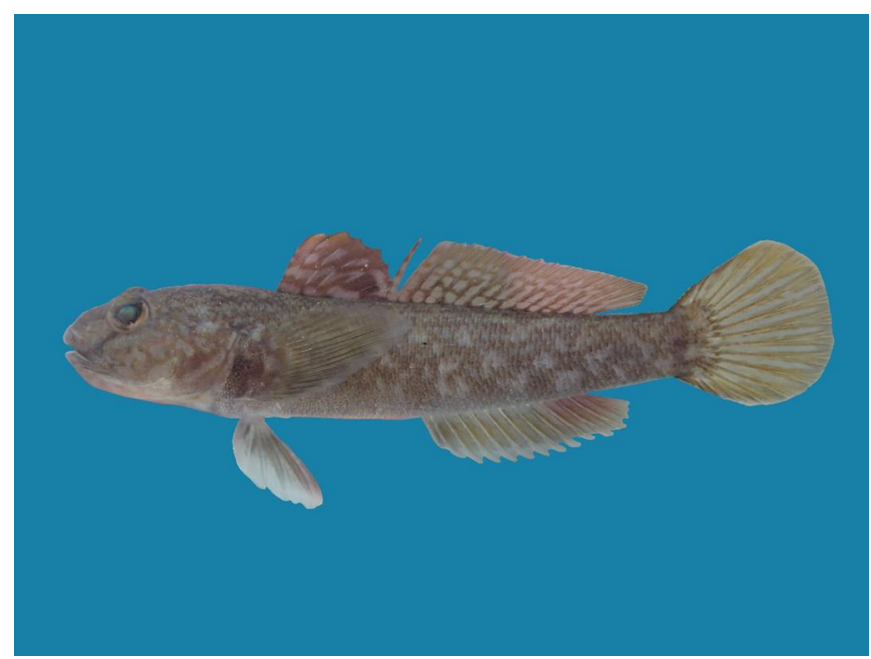

Fig. 1. Cropped photograph of Babka gymnotrachelus from Evros_MD site (93.5 mm TL). Photographed alive on-site in a field aquarium after application of clove-oil anesthetic.

about $1.7 \mathrm{~m}$. At least $400 \mathrm{~m}$ of river stretch within Greek territory was sampled at each survey site; however, benthic habitats in deeper waters were out of reach. All stunned fish were collected by the netted anode and by a second operator using a separate dip-net. After measurement and identification nearly all specimens were released alive back to the river. In this survey, non-native gobies were collected, photographed in a field aquarium, anaesthetized (using clove oil), humanly euthanized and fixed in a $98 \%$ ethanol solution for lab study (Fig. 1).

B. gymnotrachelus was found at sampling sites "Evros_MD" near Nea Vissa village and at "Evros_UP" near Ormenio village (Fig. 2). Additionally, at "Evros_MD" and at the southernmost site, "Lykofos", $N$. fluviatilis was re-located; this species was first discovered in Greek territory 24 river kilometers downstream of "Lykofos" in 2011 (Zogaris and Apostolou, 2011). A tributary site, "Erythro_DW" had no gobies; although native gobies have been found in many other tributaries (Dimitriou et al., 2012). B. gymnotrachelus specimens were collected in a variety of habitats, including muddy backwaters and deeper water near rocky groynes. The fish community in the sampled areas was rich (13-20 species per site) and the native western tubenose goby Proterorhinus semilunaris (Heckel, 1837) was by far the most abundant goby (Tab. 1).

B. gymnotrachelus specimens were identified (based on: Miller and Vasil'eva, 2003; Kottelat and Freyhof, 2007; Vassilev et al., 2012) by the following characteristics:

- the lack of a black spot on the posterior part of the first dorsal fin versus a visible black spot in Neogobius melanostomus (not present in this river);

- the first branched ray of the second dorsal fin is about as long as the penultimate ray versus the second dorsal branched fin ray, being twice as long as the penultimate ray in N. fluviatilis;

- a more roundish head versus a more flat and broader head in Ponticola kessleri (not present in this river) and versus the narrower pointed head of $N$. fluviatilis, and;

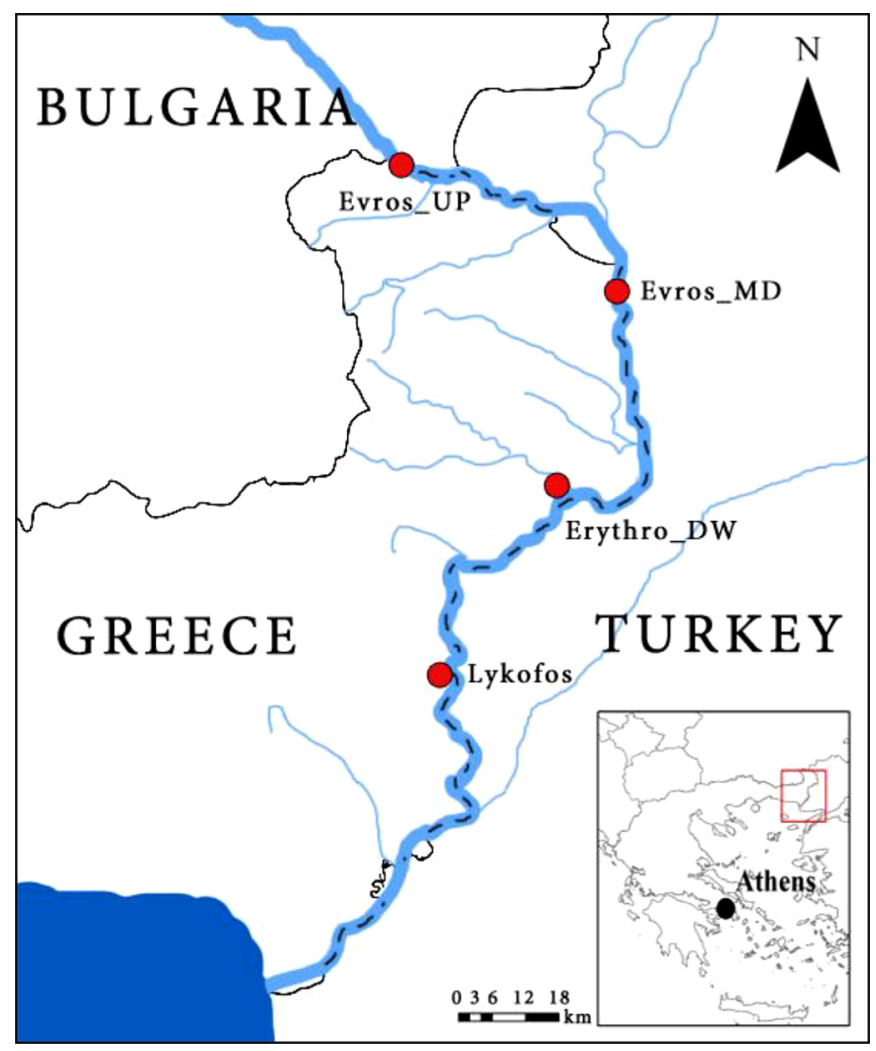

Fig. 2. EU WFD boat-based fish monitoring sites on the Evros river.

- areas without scales on the nape (this area feels very smooth when touched as compared with $N$. fluviatilis, where nape scaling gives a relatively rough texture).

In addition, the sides of $B$. gymnotrachelus often show a characteristic but variable slanting striped pattern. Since sexual maturity occurs after the second year of life, at an approximate total length (TL) greater than $5.8 \mathrm{~cm}$ (Grabowska, 2005; Cocan et al., 2016) only specimens from "Evros_MD" had reached reproductive sizes (Tab. 2). The 8 specimens from "Evros_UP" includes young-of-the-year juveniles, providing first evidence that the species probably reproduces and is therefore established in the area. The possibility of young-of-the-year fishes being recently introduced by humans at this location is highly unlikely, and this is corroborated by the older individuals collected at Evros_MD, which is 46 river kilometers downstream. All collected specimens were stored in the HCMR Fish Museum at Anavissos, Greece.

B. gymnotrachelus and other related Ponto-Caspian goby species have been assessed as "invasive" in the Balkan countries (Simonović et al., 2013), however this species' invasion progress has been poorly recorded (Roche et al., 2013; Jakšić et al., 2016; Piria et al., 2017b). Caution is needed in tracking, identification and invasiveness assessments of Ponto-Caspian gobies since even hybridization among invaders is a possibility, although probably extremely rare (Haertl et al., 2012; Lindner et al., 2013). In our case, hybridization with sympatric gobies is highly unlikely but genetic analyses and further study is recommended in order to research the provenance and mode of entry into the Evros river 
S. Zogaris et al.: Knowl. Manag. Aquat. Ecosyst. 2019, 420, 13

Table 1. Total number and size classes of gobid fishes caught at four surveyed sites.

\begin{tabular}{|c|c|c|c|c|c|c|c|c|}
\hline Site & Coordinates & River (km) & Date & Species & Total number & $<5$ & $\begin{array}{c}\text { Size class }(\mathrm{cm}) \\
6-10\end{array}$ & $11-15$ \\
\hline & $41^{\circ} 44^{\prime} 14.70^{\prime \prime} \mathrm{N} 2$ & & & Babka gymnotrachelus & 8 & 8 & 0 & 0 \\
\hline \multirow[t]{3}{*}{ Evros_UP } & $6^{\circ} 14^{\prime} 7.24 " \mathrm{E}$ & 202 & $10 / 9 / 2018$ & Proterorhinus semilunaris & 27 & 13 & 11 & 3 \\
\hline & & & & Neogobius fluviatilis & 0 & 0 & 0 & 0 \\
\hline & $41^{\circ} 34^{\prime} 17.08^{\prime \prime} \mathrm{N}$ & & & Babka gymnotrachelus & 5 & 2 & 3 & 0 \\
\hline \multirow[t]{4}{*}{ Evros_MD } & & 156 & $10 / 9 / 2018$ & Proterorhinus semilunaris & 9 & 6 & 3 & 0 \\
\hline & $26^{\circ} 35^{\prime} 12.99^{\prime \prime} \mathrm{E}$ & & & & & & & \\
\hline & & & & Neogobius fluviatilis & 7 & 6 & 1 & 0 \\
\hline & $41^{\circ} 20^{\prime} 41.08^{\prime \prime} \mathrm{N}$ & & & Babka gymnotrachelus & 0 & 0 & 0 & 0 \\
\hline \multirow[t]{3}{*}{ Erythro_DW } & $26^{\circ} 29^{\prime} 38.50^{\prime \prime} \mathrm{E}$ & 117 & $11 / 9 / 2018$ & Proterorhinus semilunaris & 0 & 0 & 0 & 0 \\
\hline & & & & Neogobius fluviatilis & 0 & 0 & 0 & 0 \\
\hline & $41^{\circ} 6^{\prime} 41.48^{\prime \prime} \mathrm{N}$ & & & Babka gymnotrachelus & 0 & 0 & 0 & 0 \\
\hline \multirow[t]{2}{*}{ Lykofos } & $26^{\circ} 18^{\prime} 12.43^{\prime \prime E}$ & 75 & $12 / 9 / 2018$ & Proterorhinus semilunaris & 76 & 70 & 6 & 0 \\
\hline & & & & Neogobius fluviatilis & 3 & 2 & 1 & 0 \\
\hline
\end{tabular}

Table 2. Babka gynotrachelus total length (mm), sex and location ( $\mathrm{MD}=$ Evros_MD, UP $=$ Evros_UP).

\begin{tabular}{|c|c|c|c|c|c|c|c|c|c|c|c|c|c|}
\hline No & 1 & 2 & 3 & 4 & 5 & 6 & 7 & 8 & 9 & 10 & 11 & 12 & 13 \\
\hline $\mathrm{TL}(\mathrm{mm})$ & 61.97 & 92.3 & 93.46 & 36.72 & 23.99 & 29.13 & 37.9 & 35.39 & 37.85 & 31.14 & 40.3 & 35.98 & 43.82 \\
\hline SEX & female & female & female & female & female & female & female & female & female & male & male & male & male \\
\hline Station & MD & MD & MD & MD & MD & UP & UP & UP & UP & UP & UP & UP & UP \\
\hline
\end{tabular}

basin (e.g. Ohayon and Stepien, 2007; Grabowski et al., 2016). In our opinion natural dispersion into the Evros by $B$. gymnotrachelus is inconceivable, despite the fact that this river is geographically close and historically related to the Black/ Marmara Sea catchments that host native populations of this and other Ponto-Caspian gobies. We hypothesize that the probable vector for invasion is the accidental transfer through fish stocking practices from the Danubian/Black Sea catchments to the Evros's Bulgarian artificial dam reservoirs. Fish stocking and unintentional angler-associated translocations are frequent in the Bulgarian part of the basin and several freshwater organisms have entered Greece and Turkey through this transboundary river (İnnal and Erk'akan, 2006; Barbieri et al., 2015; Ozulug et al., 2018). The Bulgarian part of the Evros basin has several large reservoirs, including hydroelectric dams and it is well-known that these attract amateur fishing activity were fish introductions are poorly regulated (Stefanov et al., 2008). Large numbers of young-of-the-year fishes, including alien gobiids, are known to pass through hydroelectric dam turbines and overflows (Janáč et al., 2013). Reservoir development with stocking and amateur fishing are a primary route of entry of many invasive species of fish in the Mediterranean: river basins (Clavero and Hermoso, 2011; Koutsikos et al., 2019) and elsewhere (Johnson et al., 2008).

The Evros's B. gymnotrachelus record is especially important because it provides: i) first evidence of what we presume to be an early stage invasion process; ii) preliminary data that the native $P$. semilunaris is still the most abundant goby relative to the other two non-native Ponto-Caspian gobies (at least in the shallower waters and river banks sampled); and, iii) possible indication of a downstream dispersal from Bulgaria of $B$. gymnotrachelus (the juvenile specimens at "Evros_UP" were collected literally c. $20 \mathrm{~m}$. from Bulgarian territorial waters). However, this report also shows the inadequate degree of ichthyological monitoring by the three countries sharing the Evros river. Additionally, boat-based electrofishing on its own may not be adequate for quantitative surveys of benthic gobies and other methods should also be employed (Szalóky et al., 2015; Lenhardt et al., 2017). Moreover, it is noteworthy that B. gymnotrachelus has been overlooked and its establishment status was undefined until recently even in several Danube tributaries (Roche et al., 2013; Piria et al., 2017b); the species is probably overlooked in the Bulgarian and Turkish stretches of the Evros also. This species should obviously be present in the Bulgarian part of the Evros but there are no published records to our knowledge (Vassilev et al., 2012; Yankova, 2016). Biological pollution problems such as the expansion of non-native Ponto-Caspian gobies, which are a potential pressure on biotic communities (Roche et al., 2013), is also a reason for international cooperation in monitoring and management of this important transboundary river (Dimitriou et al., 2012; Trebitz et al., 2017).

Acknowledgements. The monitoring project is supported by the Special Secretariat for Water, Ministry of Environment and Energy and by European Union funding. We thank D. Kommatas who shares responsibility in the boat-based 
electrofishing unit and E. Dimitriou who heads the WFD monitoring project at HCMR. We are grateful to colleagues in Bulgaria and Turkey who assisted us with their knowledge of this shared river.

\section{References}

Barbieri R, Zogaris S, Kalogianni E, Stoumboudi M Th, Chatzinikolaou Y, Giakoumi S, Kapakos Y, Kommatas D, Koutsikos N, Tachos V, Vardakas L, Economou AN. 2015. Freshwater fishes and Lampreys of Greece: An annotated checklist. Athens, Greece: Monographs on Marine Sciences No. 8, Hellenic Centre for Marine Research, p. 134.

Clavero M, Hermoso V. 2011. Reservoirs promote the taxonomic homogenization of fish communities within river basins. Biodivers Conserv 20: 41-57.

Cocan DI, Oțel V, Laţiu C, Păpuc T, Miresan V. 2016. A new species of the Gobiidae family in Transylvania waters: Racer goby (Babka gymnotrachelus, Kessler 1857). Bull UASVM Anim Sci Biotechnol 73(2): 183-191.

Dimitriou E, Mentzafou A, Zogaris S, Tzortziou M, Gritzalis K, Karaouzas I, Nikolaidis Ch. 2012. Assessing the environmental status and identifying the dominant pressures of a transboundary river catchment, to facilitate efficient management and mitigation practices. Environ Earth Sci 66(7): 1839-1852.

Economou AN, Zogaris S, Vardakas L, Koutsikos N, Chatzinikolaou Y, Kommatas D, Kapakos Y, Giakoumi S, Oikonomou E, Tachos V. 2016. Developing policy-relevant river fish monitoring in Greece: Insights from a nation-wide survey. Mediter Mar Sci 171: 302-322.

Grabowska J. 2005. Reproductive biology of racer goby Neogobius gymnotrachelus in the Wloclawski Reservoir (Vistula River, Poland). J Appl Ichthyol 21: 296-299.

Grabowski M, Hupalo K, Bylak A, Kukula K, Grabowska J. 2016. Double origin of the racer goby (Babka gymnotrachelus) in Poland revealed with mitochondrial marker. Possible implications for the species alien/native status. J Limnol 75: 101-108.

Haertl M, Cerwenka AF, Brandner J, Borcherding J, Geist J, Schliewen UK. 2012. First record of Babka gymnotrachelus (Kessler, 1857) from Germany (Teleostei, Gobiidae, Benthophilinae). Spiliana 35: 155-159.

İnnal D, Erk'akan F. 2006. Effects of exotic and translocated fish species in the inland waters of Turkey. Rev Fish Biol Fisher 16: 39-50.

Jakšić G, Jadan M, Piria M. 2016. The review of ecological and genetic research of Ponto-Caspian gobies (Pisces, Gobiidae) in Europe. Croat J Fish 74(3): 110-123.

Janáč M, Jurajda P, Kružíková L, Roche K, Prášek P. 2013. Reservoir to river passage of age- $0+$ year fish, indication of the dispersion pathway for a non-native species. J Fish Biol 82(3): 994-1010.

Johnson PT, Olden JD, Vander Zanden MJ. 2008. Dam invaders: Impoundments facilitate biological invasions into freshwaters. Front Ecol Environ 6: 357-363.

Kottelat M, Freyhof J. 2007. Handbook of European freshwater fishes. Berlin, Germany: Kottelat, Cornol, Switzerland, Freyhof, $646 \mathrm{p}$.

Koutsikos N, Zogaris S, Vardakas L, Kalantzi O, Dimitriou E, Economou NA. 2019. Tracking non-indigenous fishes in lotic ecosystems: Invasive patterns at different spatial scales in Greece. Sci Tot Environ 659: 384-400.

Lenhardt M, Pekarik L, Skorić SB, Smederevac-Lalić MM, Hegediš AE, Jaćimović ML, Đikanović V. 2017. Influence of the twilight period and different sampling methods on catch of Gobiids
(Gobiidae) at four locations in the inshore parts of the Danube River. Acta Zool Bulg 9: 225-229.

Lindner K, Cerwenka AF, Brandner J, Gertzen S, Borcherding J, Geist J, Schliewen UK. 2013. First evidence for interspecific hybridization between invasive goby species Neogobius fluviatilis and Neogobius melanostomus (Teleostei: Gobiidae: Benthophilinae). $J$ Fish Biol 82(6): 2128-2134.

Miller PJ, Vasil'eva ED. 2003. Neogobius Iljin, 1927. In: Miller PJ, eds. The freshwater fishes of Europe Vol. 8/I Mugilidae, Atherinidae, Atherinopsidae, Blenniidae, Odontobutidae, Gobiidae 1, Vol. 8/I. Wiebelsheim, Germany: AULA Verlag, pp. 163-171.

Ohayon JL, Stepien CA. 2007. Genetic and biogeographic relationships of the racer goby Neogobius gymnotrachelus (Gobiidae: Teleostei) from introduced and native Eurasian locations. J Fish Biol 71: 360-370.

Ozulug M, Gaygusuz O, Gaygusuz CG, Sac G. 2018. New distribution areas of four invasive freshwater fish species from Turkish Thrace. Turk J Fish Aquat Sci 19(10): Accepted manuscript doi: org/10.4194/1303-2712-v19 10 03.

Piria M, Simonović P, Kalogianni E, Vardakas L, Koutsikos N, Zanella D, Ristovska M, Apostolou A, Adrović A, Mrdak D, Tarkan AS, Milošević D, Zanella LN, Bakiu R, Ekmekçi FG, Povž M, Korro K, Nikolić V, Škrijelj R, Kostov V, Gregori A, Joy MK. 2017a. Alien freshwater fish species in the Balkans-vectors and pathways of introduction. Fish Fish 19(1): 1-32.

Piria M, Marčić Z, Jakšić G, Horvatić S, Zanella D. 2017b. Has the racer goby Babka gymnotrachelus (Kessler, 1857) failed to invade the Croatian tributaries of the Danube River? In: Trichkova T, Tomov R, Vladimirov V, Kalcheva H, Vanev Y, Uludag A, Tyufekchieva V, eds. Book ofAbstracts, 7th ESENIAS Workshop with Scientific Conference' Networking and Regional Cooperation Towards Invasive Alien Species Prevention and Management in Europe', 28-30 March 2017. Sofia, Bulgaria: IBER-BAS, ESENIAS, $168 \mathrm{p}$.

Roche KF, Janač M, Jurajda P. 2013. A review of Gobiid expansion along the Danube-Rhine corridor-geopolitical change as a driver for invasion. Knowl Managt Aquatic Ecosyst 411: 01.

Simonović P, Tošić A, Vassilev M, Apostolou A, Mrdak D, Ristovska M, Kostov V, Nikolić V, Škraba D, Vilizzi L, Copp G. 2013. Risk assessment of non-native fishes in the Balkans region using FISK, the invasiveness screening tool for non-native freshwater fishes. Medit Mar Sci 14(2): 369-376.

Stefanov T, Vassilev M, Dobrev D. 2008. First occurrence of Neogobius fluviatilis (Pallas, 1814) (Pisces: Gobiidae) in the Aegean sea watershed. Acta Zool Bulgar 60(3): 331-334.

Szalóky Z, Bammer V, György ÁI, Pehlivanov L, Schabuss M, Zornig H, Weiperth A, Eros T. 2015. Offshore distribution of invasive gobies (Pisces: Gobiidae) along the longitudinal profile of the Danube River. Fund Appl Limnol 187(2): 127-133.

Trebitz AS, Hoffman JC, Darling JA, Pilgrim EM, Kelly JR, Brown EA, Chadderton WL, Egan SP, Grey EK, Hashsham SA, Klymus KE. 2017. Early detection monitoring for aquatic non-indigenous species: Optimizing surveillance, incorporating advanced technologies, and identifying research needs. $J$ Environ Manage 202: 299-310.

Vassilev M, Apostolou A, Velkov B, Dobrev B, Zarev V. 2012. Atlas of the gobies (Gobiidae) in Bulgaria. Sofia, Bulgaria: Institute of Biodiversity and Ecosystem Research, Bulgarian Academy of Sciences, $113 \mathrm{p}$.

Yankova M. 2016. Alien invasive fish species in Bulgarian waters: An overview. Int J Fish Aquat Stud 4: 282-290. 
S. Zogaris et al.: Knowl. Manag. Aquat. Ecosyst. 2019, 420, 13

Zogaris S, Apostolou A. 2011. First record of the Pontian Monkey Goby Neogobius fluviatilis (Pallas, 1814) in the Evros river (Greece). Is it an alien species? Medit Mar Sci 12(2): $454-461$.
Zogaris S, Tachos V, Economou AN, Chatzinikolaou Y, Koutsikos N, Schmutz S. 2018. A model-based fish bioassessment index for Eastern Mediterranean rivers: Application in a biogeographi graphically diverse area. Sci Tot Environ 622: 676-689.

Cite this article as: Zogaris S, Ntakis A, Barbieri R. 2019. The racer goby, Babka gymnotrachelus (Kessler, 1857) invades the Evros river: evidence of recent establishment in Greece. Knowl. Manag. Aquat. Ecosyst., 420, 13. 